University of Nebraska - Lincoln

DigitalCommons@University of Nebraska - Lincoln

Nebraska Beef Cattle Reports

Animal Science Department

2017

\title{
Evaluation of the Value of Fiber in Distillers Grains Plus Solubles on Performance of Finishing Cattle
}

Jordan E. Burhoop

University of Nebraska-Lincoln, jordanburhoop_28@hotmail.com

Liesel J. Schneider

University of Nebraska-Lincoln

Curtis J. Bittner Bittner

University of Nebraska Lincoln, curtis.bittner@unl.edu

F. Henry Hilscher

University of Nebraska-Lincoln, henry.hilscher@unl.edu

Jim C. MacDonald

University of Nebraska-Lincoln, jmacdonald2@unl.edu

See next page for additional authors

Follow this and additional works at: https://digitalcommons.unl.edu/animalscinbcr

Part of the Large or Food Animal and Equine Medicine Commons, Meat Science Commons, and the Veterinary Preventive Medicine, Epidemiology, and Public Health Commons

Burhoop, Jordan E.; Schneider, Liesel J.; Bittner, Curtis J. Bittner; Hilscher, F. Henry; MacDonald, Jim C.; Moxley, Rodney A.; Smith, David R.; and Erickson, Galen E., "Evaluation of the Value of Fiber in Distillers Grains Plus Solubles on Performance of Finishing Cattle" (2017). Nebraska Beef Cattle Reports. 923. https://digitalcommons.unl.edu/animalscinbcr/923

This Article is brought to you for free and open access by the Animal Science Department at DigitalCommons@University of Nebraska - Lincoln. It has been accepted for inclusion in Nebraska Beef Cattle Reports by an authorized administrator of DigitalCommons@University of Nebraska - Lincoln. 


\section{Authors}

Jordan E. Burhoop, Liesel J. Schneider, Curtis J. Bittner Bittner, F. Henry Hilscher, Jim C. MacDonald, Rodney A. Moxley, David R. Smith, and Galen E. Erickson 


\section{Evaluation of the Value of Fiber in Distillers Grains Plus Solubles on Performance of Finishing Cattle}

\author{
Jordan E. Burhoop \\ Liesel J. Schneider \\ Curtis J. Bittner \\ F. Henry Hilscher \\ Jim C. MacDonald \\ Rodney A. Moxley \\ David R. Smith \\ Galen E. Erickson
}

\section{Summary with Implications}

A finishing study was conducted to determine the value of the fiber in distillers grains plus solubles on cattle performance. Five treatments were evaluated: a corn control diet, 20 or $40 \%$ modified distillers grains plus solubles, plus two diets containing corn germ meal and corn bran balanced to equal the fiber content of the two modified distillers grains plus solubles diets. There was a significant improvement in $A D G$ and F:G for cattle fed modified distillers grains plus solubles compared to control. Cattle fed the corn germ meal and bran diets had increased $D M I$, slightly lower $A D G$, and poorer F:G compared to the control. The isolated fiber component had $83-90 \%$ the feeding value of corn, while modified distillers grains plus solubles had 107-108\%. Other components in distillers besides fiber must improve the value of distillers compared to corn.

\section{Introduction}

Distillers grains are commonly fed in finishing diets. The ethanol industry has recently started removing components of distillers grains, such as fiber components and corn oil, which changes the nutrient content of distillers grains plus solubles that are available to be fed. In recent years, research has been done using these components to formulate diets that give the same performance as feeding distillers grains. Feeding the fiber portion resulted in the closest performance to the DGS diet in one

(C) The Board Regents of the University of Nebraska. All rights reserved. study (2016 Nebraska Beef Cattle Report, pp. 122-23). A different experiment concluded that feeding individual components did not mimic performance of WDGS, but including fiber, protein, fat and solubles combined together gave the same performance as feeding WDGS (2016 Nebraska Beef Cattle Report, pp. 124-127). These findings demonstrate that the interactions between fiber, protein, fat, and solubles in WDGS are important, and have a similar feeding value to WDGS. The objective of this study was to determine the value of the fiber in modified distillers grains plus solubles for finishing cattle performance.

\section{Procedure}

A finishing experiment conducted at the Eastern Nebraska Research and Extension Center utilized 800 crossbred yearling steers (initial BW $=915 \mathrm{lb} \pm 53 \mathrm{lb}$ ). For five days before the beginning of the trial, cattle were limit-fed a diet of $50 \%$ alfalfa and $50 \%$ Sweet Bran (DM Basis) at $2 \%$ of BW to reduce variation in gastrointestinal fill. Cattle were weighed on day 0 and 1 to establish an accurate initial BW. Steers were split into four blocks according to their initial BW with each block consisting of 200 head. A total of 100 pens were used on the study with 8 steers per pen. Pens were assigned randomly to treatment with five treatments and 20 pens per treatment. All cattle were adapted to the finishing treatments over a five step adaptation process by replacing alfalfa with dry-rolled-corn (DRC).

The five treatments consisted of a corn control diet (CON), 20\% (20MDGS) or 40\% (40MDGS) modified distillers grains plus solubles (MDGS), plus two diets formulated with corn germ meal and corn bran to equal the fiber content of the two MDGS diets (20FIB and 40FIB; Table 1). To mimic the nutrient composition of the 20MDGS treatment, the 20FIB treatment contained $1.5 \%$ solvent extracted germ meal (SEM) and 7\% wet corn bran from the wet milling industry. Likewise, the 40FIB treatment was formulated to mimic 40MDGS by adding 3\% SEM and $14 \%$ wet corn bran. On a DM basis, all diets contained 12\% high moisture corn (HMC), $8 \%$ corn silage, $3 \%$ alfalfa hay, and supplement fed at either $5 \%$ or $8 \%$. The control, 20FIB, and 40FIB had a greater inclusion of supplement because 3\% soybean meal was fed in addition to urea as a RDP source. The supplement also provided Tylan- $40^{\circledR}$ (Elanco Animal Health) at $90 \mathrm{mg}$ per steer daily and Rumensin-90 (Elanco Animal Health) at $30 \mathrm{~g}$ per ton DM.

Blocks 1, 2, and 3 were implanted with Revalor-200 99 days prior to harvest and block 4 was implanted 113 days prior to harvest. Cattle in the three heavier blocks were fed for 134 days and the light block was on feed for 148 days. Steers were shipped to Greater Omaha for slaughter, and carcass data were recorded. On day of harvest, hot carcass weight and liver score were collected. Following a 48-hour chill, USDA marbling score, LM area, and $12^{\text {th }}$ rib fat thickness were recorded. Animal performance and carcass characteristics were analyzed as an unstructured treatment design using a protected F-test, where block was included as a fixed effect. Treatment design was also analyzed as a $2 \times 2+1$ with two feed sources (MDGS or Fiber) and two inclusion levels (20 or $40 \%$ ) plus a control. Interactions for the $2 \times 2$ factorial design were evaluated. Linear and quadratic orthogonal contrasts were used to evaluate inclusion of MDGS or fiber in the diet with the control being the $0 \%$ inclusion level. Data were analyzed using the MIXED procedure of SAS (SAS Institute, Inc. Cary, N.C.), where pen was the experimental unit. Treatment differences were declared significant at $P \leq$ 0.05 . One steer from the control treatment died on day 147 and a steer from the 40MDGS treatment was removed on day 86 due to repeated bloating. These two steers were removed from performance data. 
Table 1. Composition (\% of diet DM) of dietary treatments fed to yearling steers.

\begin{tabular}{|c|c|c|c|c|c|}
\hline \multirow[t]{2}{*}{ Ingredient } & \multicolumn{5}{|c|}{ Treatment $^{1}$} \\
\hline & $\mathrm{CON}$ & 20MDGS & 40MDGS & $20 \mathrm{FIB}$ & $40 \mathrm{FIB}$ \\
\hline Dry-rolled corn & 68.5 & 51.5 & 31.5 & 60 & 51.5 \\
\hline High-moisture corn & 12 & 12 & 12 & 12 & 12 \\
\hline $\mathrm{MDGS}^{2}$ & - & 20 & 40 & - & - \\
\hline $\mathrm{SEM}^{3}$ & - & - & - & 1.5 & 3 \\
\hline Wet Corn Bran & - & - & - & 7 & 14 \\
\hline Corn Silage & 8 & 8 & 8 & 8 & 8 \\
\hline Alfalfa hay & 3.5 & 3.5 & 3.5 & 3.5 & 3.5 \\
\hline Supplement ${ }^{4}$ & - & - & - & - & - \\
\hline Fine Ground Corn & 1.228 & 2.635 & 2.899 & 1.361 & 1.856 \\
\hline Limestone & 1.615 & 1.599 & 1.585 & 1.633 & 1.604 \\
\hline Tallow & 0.2 & 0.125 & 0.125 & 0.2 & 0.2 \\
\hline Urea & 1.377 & 0.25 & - & 1.2 & 0.75 \\
\hline SBM & 3 & - & - & 3 & 3 \\
\hline Potassium Chloride & 0.189 & - & - & 0.215 & 0.199 \\
\hline Salt & 0.3 & 0.3 & 0.3 & 0.3 & 0.3 \\
\hline Beef Trace Minerals & 0.05 & 0.05 & 0.05 & 0.05 & 0.05 \\
\hline Vitamin A-D-E & 0.015 & 0.015 & 0.015 & 0.015 & 0.015 \\
\hline Rumensin- $90^{\oplus 5}$ & 0.017 & 0.017 & 0.017 & 0.017 & 0.017 \\
\hline Tylan- $40^{\boxplus 6}$ & 0.009 & 0.009 & 0.009 & 0.009 & 0.009 \\
\hline \multicolumn{6}{|c|}{ Nutrient Composition, \% of DM } \\
\hline $\mathrm{CP}$ & 14.1 & 15.1 & 19.8 & 14.1 & 13.3 \\
\hline $\mathrm{NDF}$ & 11.0 & 16.7 & 22.0 & 16.6 & 22.2 \\
\hline $\mathrm{ADF}$ & 4.5 & 6.6 & 8.6 & 6.0 & 7.5 \\
\hline Lignin & 1.7 & 2.3 & 2.9 & 1.9 & 2.2 \\
\hline \multicolumn{6}{|c|}{$\begin{array}{l}{ }^{1} \text { Treatments included CON-control; } 20 \mathrm{MDGS}-20 \% \text { modified distillers grains plus solubles; } 40 \mathrm{MDGS}-40 \% \text { modified d } \\
\text { grains plus solubles; } 20 \mathrm{FIB} \text {-fiber fed from concentrated ingredients to mimic fiber provided by } 20 \mathrm{MDGS} \text {; } 40 \mathrm{FIB} \text {-fibe } \\
\text { concentrated ingredients to mimic fiber provided by } 40 \text { MDGS. } \\
{ }^{2} \text { MDGS: Modified distillers grains plus solubles, } \\
{ }^{3} \text { SEM: solvent extracted germ meal } \\
{ }^{4} \text { Supplement fed at } 8 \% \text { of dietary DM for CON, 20FIB, and } 40 \mathrm{FIB} \text { and } 5 \% \text { of dietary DM for } 20 \mathrm{MDGS} \text { and } 40 \mathrm{MDGS} \\
{ }^{5} \text { Formulated to supply Rumensin- } 90^{\circ} \text { (Elanco Animal Health) at } 30 \mathrm{~g} \text { per ton DM } \\
{ }^{6} \text { Formulated to supply Tylan- } 40^{\circ} \text { (Elanco Animal Health) at } 90 \mathrm{mg} \text { per steer daily }\end{array}$} \\
\hline
\end{tabular}

\section{Results}

Initial BW ( $P=0.63$; Table 2$)$ was not influenced by treatment, based on allocation. Intakes were impacted by treatment $(P<0.01)$ and DMI increased with MDGS inclusion, with steers fed 20MDGS having the greatest DMI. Steers fed 40MDGS or 40FIB had similar DMI $(P=0.76)$, whereas steers fed 20MDGS consumed more $(P<$ $0.01)$ than steers fed 20FIB. When 40FIB was fed, DMI increased linearly $(P=0.01)$ relative to CON. Dietary treatment impacted ADG $(P<0.01)$, as ADG increased with MDGS inclusion, and equal ADG between 20MDGS and 40MDGS $(P=0.96)$. Feeding 20FIB and 40FIB slightly reduced ADG but not statistically $(P>0.14)$ compared to CON. As a result of increased ADG, F:G improved linearly $(P<0.01)$ for steers fed MDGS. When steers were fed 20FIB or 40FIB, F: G increased linearly $(P<0.01)$ due to an increase in DMI and numerical decrease in ADG compared to CON. The feeding value of MDGS relative to corn (difference between test G:F and control G:F divided by control G:F, then divided by by-product inclusion level) was $107 \%$ for 20MDGS and $108 \%$ of corn for 40 MDGS. The isolated fiber treatments had feeding values that were lower than the control at $83 \%$ for $20 \mathrm{FIB}$ and $90 \%$ for $40 \mathrm{FIB}$. The cattle performed as expected with the MDGS treatments showing the best performance and the fiber treatments having reduced performance. Steers on the MDGS treatments had the greatest $\mathrm{HCW}(P<0.01)$ and fat thickness $(P<0.01)$ compared to the other three treatments. Cattle fed 20MDGS had the highest marbling $(P<0.01)$, with the other four treatments being lower and not significantly different from each other. 
Table 2. Effect of feeding modified distillers grains (MDGS) at 20 or $40 \%$ compared to fiber to mimic NDF provided by 20 or $40 \%$ MDGS on feedlot performance and carcass characteristics

\begin{tabular}{|c|c|c|c|c|c|c|c|c|c|c|}
\hline & \multicolumn{5}{|c|}{ Treatment $^{1}$} & SEM & \multicolumn{4}{|c|}{$\mathrm{P}$-values ${ }^{2}$} \\
\hline Initial BW, lb & 915 & 916 & 916 & 915 & 915 & 0.9 & 0.63 & 0.53 & 0.26 & 0.89 \\
\hline Final BW, $\mathrm{lb}^{3}$ & $1439^{\mathrm{b}}$ & $1473^{\mathrm{a}}$ & $1472^{\mathrm{a}}$ & $1428^{\mathrm{b}}$ & $1429^{\mathrm{b}}$ & 5.5 & $<0.01$ & 0.90 & $<0.01$ & 0.96 \\
\hline ADG, lb & $3.81^{\mathrm{b}}$ & $4.05^{\mathrm{a}}$ & $4.04^{\mathrm{a}}$ & $3.73^{\mathrm{b}}$ & $3.74^{\mathrm{b}}$ & 0.04 & $<0.01$ & 0.93 & $<0.01$ & 0.98 \\
\hline $\mathrm{F}: \mathrm{G}$ & $6.75^{\mathrm{b}}$ & $6.64^{\mathrm{ab}}$ & $6.53^{\mathrm{a}}$ & $6.97^{\mathrm{c}}$ & $7.03^{c}$ & - & $<0.01$ & 0.09 & $<0.01$ & 0.47 \\
\hline \multicolumn{11}{|c|}{ Carcass Characteristics } \\
\hline $12^{\text {th }}$ rib fat, in & $0.53^{\mathrm{b}}$ & $0.58^{\mathrm{a}}$ & $0.59^{\mathrm{a}}$ & $0.52^{\mathrm{b}}$ & $0.55^{\mathrm{b}}$ & 0.01 & $<0.01$ & 0.27 & $<0.01$ & 0.12 \\
\hline Liver Abscess $(\mathrm{n})^{5}$ & 10 & 7 & 15 & 12 & 9 & - & 0.59 & 0.14 & 0.99 & 0.54 \\
\hline
\end{tabular}

a-c Means with different subscripts differ $(\mathrm{P}<0.05)$

${ }^{1}$ Treatments included CON-control; 20MDGS-20\% modified distillers grains plus solubles; 40MDGS-40\% modified distillers grains plus solubles; $20 \mathrm{FIB}-$ fiber fed from concentrated ingredients to mimic fiber provided by 20MDGS; 40FIB-fiber fed from concentrated ingredients to mimic fiber provided by 40MDGS.

${ }^{2} \mathrm{INT}=$ interaction between fiber source and inclusion, SOURCE $=$ P-value for main effect of fiber source, INCLUSION = main effect of fiber or MDGS inclusion.

Calculated from HCW/common dressing percentage (63\%)

${ }^{4}$ Marbling score: $400=$ Slight $^{00}, 450=$ Slight $^{50}, 500=$ Small $^{10}, 550=$ Small $^{50}$

${ }^{5}$ Liver Abscess Score: total number of A-, A, or A+ liver scores per treatment (159 or 160 steers per treatment group). Only two steers were observed with A+ abscesses.

\section{Conclusion}

These data illustrate that F:G was poorer if only the fiber components that typically comprise distillers grains replace corn. These data suggest that the isolated fiber component does not give equal performance to feeding MDGS. It is unclear what impact a removal of a portion of the fiber from distillers may have, if other components are concentrated. These data are based on fiber isolated from the wet milling process, but presumably applies for fiber from distillers grains plus solubles as both are isolated from corn grain.
Jordan E. Burhoop, graduate student

Liesel J. Schneider, graduate student, Mississippi State University

Curtis J. Bittner, research technician

F. Henry Hilscher, research technician

Jim C. MacDonald, associate professor Animal Science, Lincoln

Rodney A. Moxley, School of Veterinary Medicine and Biomedical Sciences, Lincoln

David R. Smith, professor, Mississippi State University

Galen E. Erickson, professor Animal

Science, Lincoln 